\title{
SETRATEGI PENINGKATAN KEAKTIFAN DAN HASIL BELAJAR PAI SISWA KELAS VII D SMP NEGERI 2 PENAWANGAN MELALUI MODEL PEMBELAJARAN COOPERATIVE SCRIPT
}

\author{
MUSTAQHFIRIN \\ SMP Negeri 2 Penawangan Kab. Grobogan Jawa Tengah \\ mfirin5@gmail.com
}

\begin{abstract}
ABSTRAK
Penelitian ini bertujuan untuk mengetahui keaktifan dan hasil belajar PAI siswa kelas VII D SMP Negeri 2 Penawangan melalui metode pembelajaran Cooperative Script . Penelitian yang digunakan adalah Penelitian Tindakan Kelas (PTK) dengan alat pengumpul data dari observasi, tes dan dokumentasi. Hasil Penelitian menunjukkan bahwa melalui metode cooperative script mampu meningkatkan keaktifan dan hasil belajar Siswa. Penelitian tindakan kelas ini dilakukan dalam dua siklus. Analisis yang digunakan dalam penelitian ini adalah teknik analisis deskriptif kualitatif dengan persentase. Kondisi Pra Siklus,Siklus I dan II menunjukkan bahwa prosentase keaktifan siswa ketegori rendah mengalami penurunan dari 66,66\% - 55,55\% $22,22 \%$, kategori sedang mengalami peningkatan dari $29,62 \%-33,33 \%-59,26 \%$ kategori tinggi dari 3,70\% - 11,11\% - 18,52\%, melalui Penerapan metode cooperative script mampu meningkatkan hasil belajar siswa, hal ini dapat dilihat data perolehan nilai pada Pra siklus - siklus I - Siklus II secara berurutan, dari 27 siswa yang belum tuntas KKM 75 mulai 59,3\% - 48,15\% - 14,81\%, siswa yang mencapai KKM 75 dari $40,74 \%-51,84 \%$ - 85,19\% dengan peningkatan nilai rata-rata kelas dari 74,81 - 77,04 - 85,19 setelah adanya tindakan.
\end{abstract}

\section{Kata kunci : Metode Cooperative Script, Keaktifan, Hasil Belajar}

\section{PENDAHULUAN}

Pembaharuan dalam bidang pendidikan harus selalu dilakukan guna untuk meningkatkan kualitas pendidikan nasional, baik dalam pembaharuan kurikulum, peningkatan kualitas pembelajaran, dan keefektifan metode pembelajaran. Warsono dan hariyanto (2014:14-15). Pendidikan harus memperhatikan perkembangan jasmani dan rohani anak didik menuju terbentuknya kepribadian yang utama, menekankan pengembangan potensi yang dimiliki Siswa secara maksimal Tafsir (2011:32). Melalui proses pembelajaran yang aktif akan mampu mengaktifkan siswa dalam pembelajaran dengan setrategi pembelajaran berbasis siswa.

Pengelolaan kelas yang baik oleh Pendidik dapat menjaga kelas tetap kondusif dalam proses pembelajaran, penting sekali bagi Pendidik Pendidikan Agama Islam menggunakan metode pembelajaran yang lebih kreatif dan inovatif, agar siswa dapat memberikan umpan balik yang positif sehingga akan meningkatkan minat, simpati dan keingintahuan yang mendalam terhadap mata pelajaran Pendidikan Agama Islam. Pengalaman belajar hanya dapat diperoleh jika siswa berpartisipasi secara aktif. Bentuk 
belajar secara aktif meliputi interaksi antara Pendidik dengan siswa, siswa dengan siswa lainnya, sekolah dengan rumah, sekolah dengan masyarakat dan Siswa dengan segala macam alat serta media pembelajaran. Berdasarkan pengamatan peneliti di SMP Negeri 2 Penawangan ditemukan fakta bahwa keaktifan siswa dalam pembelajaran masih kurang serta hasil belajar siswa pada materi PAI secara umum tergolong rendah. Hal itu bisa dilihat dari berbagai aktifitas siswa selama pelajaran PAI seperti : 1) Siswa suka ngobrol dengan temanya diluar materi pelajaran; 2) Siswa masih dijumpai main HP/game pada waktu kegiatan pembelajaran; 3) Sedikitnya Siswa yang mengajukan pertanyaan setelah diberikan bahan tanyang, atau wacana; 4) Sedikitnya Siswa yang kritis terhadap permasalahan yang berkaitan dengan materi; 5) Belum sepenuhnya materi dikuasai siswa setelah pembelajaran akibat kurang aktifnya dalam pembelajaran.

Model Pembelajaran Cooperative merupakan salah satu bentuk pembelajaran yang berdasarkan faham kontruktivis dengan diterapkan setrategi belajar sejumlah siswa sebagai anggota kelompok kecil yang tingkat kemampuanya berbeda, dalam kelompok tersebut harus saling bekerja sama dan saling membantu untuk memahami pelajaran, dalam pelajaran ini dikatakan belum selesai jika salah satu teman dalam kelompok belum menguasai bahan pelajaran, Hamdani (2011:30) Model Cooperative Script bisa melatih pendengaran siswa, ketelitian dan mengungkapkan kesalahan orang lain secara lisan, selain itu siswa bisa berbagi ide atau informasi yang dimilikinya dan berkomunikasi dengan gaya bahasa mereka sendiri. (Mariani Natalina, Nursal dan Srini: 2013)

Model pembelajaran Cooperative Script dapat diterapkan pada pembelajaran yang bersifat kognitif, karena setiap Siswa nantinya diberikan materi ajar secara lengkap, dibagi berpasang-pasangan dan masing-masing dari mereka bergantian secara lisan mengintisarikan materi yang telah diberikan, dan pasangan lainnya mengoreksi apakah benar pernyataan yang diungkapkan oleh temannya tersebut atau tidak. (Rima Meilani , Nani Sutarni: 2016). Model pembelajaran ini menuntut siswa untuk selalu aktif dalam proses pembelajaran mulai dari awal pembelajaran sampai akhir pembelajaran (Aisjah Juliani Noor, Norlaila: 2014). terdapat perbedaan keaktifan pada proses belajar antara penerapan pembelajaran model Cooperative Script dan pembelajaran konvensional serta hasil belajar lebih baik (Nurulita Sufazen: 2014) dari berbagai hasil peneltian tersebut menambah kenyakinan peneliti bahwa model pembelajaran Cooperative Script dapat meningkatkan keaktifan dan hasil belajar siswa.

Hasil pengamatan Peneliti di kelas VII D SMP Negeri 2 Penawangan, siswa yang memiliki keaktifan rendah 18/27 (66,66\%), keaktifan sedang 8/27 (29,62\%) keaktifan tinggi hanya $1 / 27(3,70 \%)$. Sedangkan dilihat dari hasil penilaian yang dilaksanakan oleh Pendidik pada kelas VII yang menyatakan bahwa Siswa yang mendapat nilai dibawah Kriteria Ketuntasan Minimal) mencapai 16/27 (59,26\%) yang mencapai/melampaui KKM hanya 11/27 (40,74\%) harapan setelah proses pembelajaran dengan Model Pembelajaran Cooperative script keaktifan Siswa meningkat minimal $10 \%$ dari kategori keaktifan sedang dan keaktifan tinggi dan mengalami penurunan minimal $20 \%$ dari kategori rendah. 
Dari analisis masalah tersebut penulis mencoba melakukan upaya peningkatan keaktifan dan hasil belajar siswa dengan penerapan model pembelajaran Cooperative Script, karena pada metode ini diharapkan muncul aktivitas dan kreatifitas siswa dalam pembelajaran, metode ini memotivasi siswa memberikan pemahaman pada pasanganya dan pemberian kesempatan menyampaikan materi dan mendengarkan paparan materi, hal ini akan menumbuhkan rasa tanggungjawab diri sendiri dan teman sebaya untuk menguasai materi, dengan penguasaan materi yang baik diharapkan hasil belajar akan mengalami peningkatan. Judul penelitian yang akan dilakukan adalah Strategi Peningkatan keaktifan dan hasil belajar PAI Siswa kelas VII D SMP Negeri 2 Penawangan melalui model pembelajaran Cooperative Script.

\section{METODE PENELITIAN}

Penelitian ini dilaksanakan di SMP Negeri 2 Penawangan yang beralamat di jalan Sedadi - Penawangan no 49, sekitar $12 \mathrm{KM}$ dari jalan raya purwodadi Semarang. Sasaran penelitian ini pada kelas VII D dengan jumlah Siswa 27 dengan rincian laki-laki 13 dan perempuan 14. Siswa kelas VII D memiliki latar belakang kehidupan sosial yang beraneka ragam, demikian pula keaktifan dan motivasi belajar juga beragam, ada yang keaktifan rendah, sedang dan tinggi, hasil belajar siswapun bervariasi dengan kategori tidak tuntas, tercapai dan terlampaui dari Kreteria Ketuntasan Minimal (KKM).

Penelitian ini adalah Penelitian Tindakan Kelas (PTK), PTK dilaksanakan dalam bentuk proses pengkajian berdaur 4 tahap, yaitu (1) Merencanakan, (2) melakukan tindakan (3) mengamati (observasi) dan (4) merefleksi, secara sistematis prosedur PTK yang akan dilakukan sebagai berikut : Pelaksanaan dalam setiap Siklus terdiri dari a) Perencanaan Tindakan (Plan) Siklus I dan II Pada tahapan ini peneliti melakukan kegiatan-kegiatan berikut ini: 1) Menetapkan SK/KD yang (sesuai waktu/kalender akademik), 2) Menetapkan indikator pencapaian (IPK), 3) Menetapkan masalah yang akan ditingkatkan, yakni "keaktifan dan hasil belajar siswa", 4) Menetapkan model pembelajaran yang akan digunakan, yaitu model pembelajaran Cooperative Script, 5) Menyusun rencana pembelajaran dengan menggunakan model pembelajaran Cooperative Script untuk 2 kali pertemuan setiap siklus. 6) Menyusun instrument untuk memperoleh data, yakni dengan menggunakan tes sesuai indikator yang akan dicapai. 7) Menetapkan 2 rekan sebagai observer/kolaborator untuk membantu melakukan observasi selama proses pembelajaran.

Proses Pembelajaran melalui metode Cooperative Script. dilaksanakan sesuai dengan RPP yang telah disusun. Pada saat yang sama, dilakukan pula observasi. Hasil dari setiap siklus diamati, dikaji dan refleksi dengan 2 observer untuk perbaikan pada siklus berikutnya apabila belum mencapai tujuan sesuai indikator keberhasilan penelitian. Peneliti dan 2 Observer melaksanakan observasi terhadap keaktifan Siswa dalam proses kegiatan pembelajaran melalui metode Cooperative Script dan mendiskusikan hasilnya. Observer melakukan pengamatan dan mencatat tindakan dari Peneliti yang berupa langkah-langkah pembelajaran dengan metode Cooperative Script Kemudian dilakukan evaluasi melalui tes tertulis untuk mrengetahui apakah keaktifan dan hasil belajar Siswa sudah meningkat atau belum. 
Dalam setiap siklus dilakukan refleksi terhadap pembelajaran melalui metode Cooperative Script yang sudah berlangsung. Pada tahap ini Peneliti dan 2 Observer menganalisis perubahan yang terjadi pada Siswa dan suasana kelas dan hal-hal yang terjadi selama proses pembelajaran berlangsung. Siswa juga diberi kesempatan untuk mengemukakan pendapat dan memberi masukan tentang apa yang dialami untuk penyempurnaan tindakan berikutnya. Dari hasil lembar observasi dan post tes dilihat apakah tindakan yang dilakukan Peneliti menghasilkan perubahan atau tidak, apabila belum mencapai sesuai indikator keberhasilan maka perlu direncanakan perbaikan pada siklus berikutnya.

Data yang diperlukan dalam penelitian ini berupa dua data primer yaitu 1) Hasil observasi langsung terhadap aktivitas Siswa selama proses pembelajaran dan 2) hasil belajar melalui tes tertulis. Instrumen yang digunakan untuk pengumpulan data penelitian ini adalah: 1) Lembar Observasi yang berupa : Lembar observasi tentang keaktifan Siswa dalam kegiatan pembelajaran menggunakan metode Cooperative Script. 2) Soal tes: Soal tes atau uji kompetensi tertulis disusun peneliti dalam bentuk soal pilihan ganda setiap selesai melakukan tindakan. 3) Dokumentasi untuk mengambil data informasi dan hasil belajar PAI Siswa kelas VII D serta foto-foto pelaksanaan tindakan yang berkaitan dengan pembelajaran.

Teknik analisis data adalah proses mengatur urutan data, mengorganisasikan ke dalam suatu pola, kategori dan satuan uraian dasar. Analisis data dalam Penelitian Tindakan Kelas (PTK) ini dilakukan sejak sebelum, selama dan setelah proses pembelajaran metode Cooperative Script, melalui instrumen yang dipilih dan akan digunakan untuk menjawab masalah dalam penelitian atau untuk menguji hipotesa yang diajukan peneliti melalui penyajian data. Untuk mengetahui peningkatan keaktifan Siswa dalam proses pembelajaran dengan menerapkan metode pembelajaran Cooperative Script, maka data yang diperlukan berupa data pengamatan dari Observer tentang perilaku Siswa selama proses pembelajaran dengan enam sikap keaktifan yang diamati dengan ketentuan: Jika suatu sikap dilakukan mendapat skor 1, jika tidak dilakukan skor 0 , sedangkan untuk kategori keaktifan ada 3 macam yaitu: 1) Keaktifan rendah jika skor total $=1-3,2$ ) Keaktifan sedang jika skor total $=4-6$, dan 3) Keaktifan tinggi jika skor total $=7-8$.

Hasil belajar yang diperoleh dari nilai tes atau uji kompetensi Siswa dianalisis dengan teknik analisis hasil evaluasi untuk mengetahui ketuntasan belajar dengan cara menganalisis data hasil tes dengan kriteria ketuntasan belajar, prosentase dengan KKM (Kriteria Ketuntasan Minimum) yang telah ditentukan. Siswa dapat dikatakan tuntas belajar jika telah mencapai mencapai nilai =/> KKM 75, hasil belajar yang diperoleh Siswa tersebut kemudian dibandingkan dengan jumlah skor maksimum kemudian dikalikan $100 \%$ atau digunakan rumus Percentages Correction.

Indikator Keberhasilan pada penelitian ini, dilihat dari data kualitatif yang berupa kegiatan Guru, keaktifan Siswa dan hasil belajar Siswa dari setiap siklus, Keaktifan Siswa dilihat dari 8 aspek yaitu : 1) Aktifitas Membentuk kelompok, 2) Diskusi dalam kelompok, 3) Menyampaikan gagasan/ide, 4) Berfikir kritis tentang pelajaran, 5) Menyelesaikan masalah, 6) Peduli pada sesama, 7) Mengajukan pertanyaan, 8) Menjawab pertanyaan. Indikator keberhasilan penelitian ini dari data 
kuantitatif peningkatan keaktifan Siswa dari setiap siklus sebagai berikut : 1) Keaktifan Siswa Pra siklus kategori rendah 66,66\% mengalami penurunan pada akhir tindakan minimal sebesar $30 \% .=36,66 \%, 2)$ Kategori sedang pada pra siklus $29,62 \%$ mengalami kenaikan pada tindakan akhir minimal sebesar $20 \%,=49,62 \%, 3$ ) Kategori keaktifan tinggi dari Pra siklus 3,70\% mengalami peningkatan minimal $10 \%$ pada akhir tindakan $=13,70 \%$. Indikator keberhasilan pada mata pelajaran PAI melalui metode pembelajaran Cooperative Script adalah : 1) Perolehan nilai (tidak tuntas)/< KKM dari pra siklus sebesar 59,26\% mengalami penurunan minimal $10 \%$ pada siklus 1 dan siklus II, 2)Perolehan Nilai (tuntas)/=> KKM dari pra siklus sebesar 40,74\% mengalami kenaikan minimal $10 \%$ pada siklus 1 dan siklus II. 3) Perolehan Nilai (tuntas)/=> KKM Siswa diperoleh minimal 80\% Siswa kelas VII D dengan rata-rata nilai minimal 78,00 .

\section{HASIL DAN PEMBAHASAN}

Tindak lanjut untuk membantu memecahkan masalah yang terkait dengan keaktifan dan hasil belajar Pendidikan Agama Islam, maka perlu melakukan perencanaan perbaikan pembelajaran dengan mendata penyebab rendahnya keaktifan dan kesulitan Siswa dalam memahami pelajaran, sehingga hasil belajar akan mengalami peningkatan, selain itu mencari solusi dari penyebab pembelajaran belum berhasil.

\section{SIKLUS I}

Rencana tindakan pada siklus I untuk memperbaiki keaktifan dan hasil belajar Siswa dibuat Rencana Pelaksanaan Pembelajaran (RPP) untuk 2 kali pertemuan, RPP Dikembangkan dengan menggunakan metode Pembelajaran Cooperative Script sesuai dengan langkah-langkah Pembelajaran yang direncanakan (secara detail tertuang dalam RPP) adalah: Langkah yang harus dilakukan dalam metode pembelajaran Cooperative Script sebagaimana yang dinyatakan dalam buku slavin (1995) yang berjudul Cooperative Learning sebagai berikut: 1) Guru membagi Siswa ke dalam kelompok secara berpasangan; 2) Guru membagi wacana/materi untuk dibaca dan dibuat ringkasannya; 3) Guru dan Siswa menetapkan siapa yang pertama berperan sebagai pembicara dan siapa yang berperan sebagai pendengar; 4) Pembicara membacakan ringkasannya selengkap mungkin dengan memasukan ide-ide pokok ke dalam ringkasannya. Selama proses pembacaan, Peseta didik lain harus menyimak/menunjukkan ide-ide pokok yang kurang lengkap dan membantu mengingat dan menghafal ide-ide pokok dengan menghubungkannya dengan materi sebelumnya atau dengan materi lainnya. 5) Siswa bertukar peran, yang semula sebagai pembicara ditukar menjadi pendengar dan sebaliknya; 6) Guru dan Siswa melakukan kembali kegiatan seperti di atas; 7) Guru dan Siswa bersama-sama membuat kesimpulan materi pelajaran; 8) Refleksi akhir; 9) Evaluasi, Warsono dan Hariyanto (2014: 205-206)

Pengamatan terhadap pelaksanaan pembelajaran pada siklus I yang dilakukan terhadap Guru dilakukan oleh 2 Observer dalam pelaksanaan sintak model pembelajaran Cooperative Script dengan memberikan skor pelaksanaanterhadap 
sintak, jika sintak tidak dilaksanakan $=0$, dilaksanakan cukup $=1$, dilaksanakan baik $=2$, dilaksakanakan dengan sangat baik $=3$, skor akhir adalah skor perolehan dibagi skor maksimal dikalikan 100\%. Dari pengamatan 2 Observer dalam 2 pertemuan didapatkan skor rata-rata data pelaksanaan sintak dalam grafik berikut :

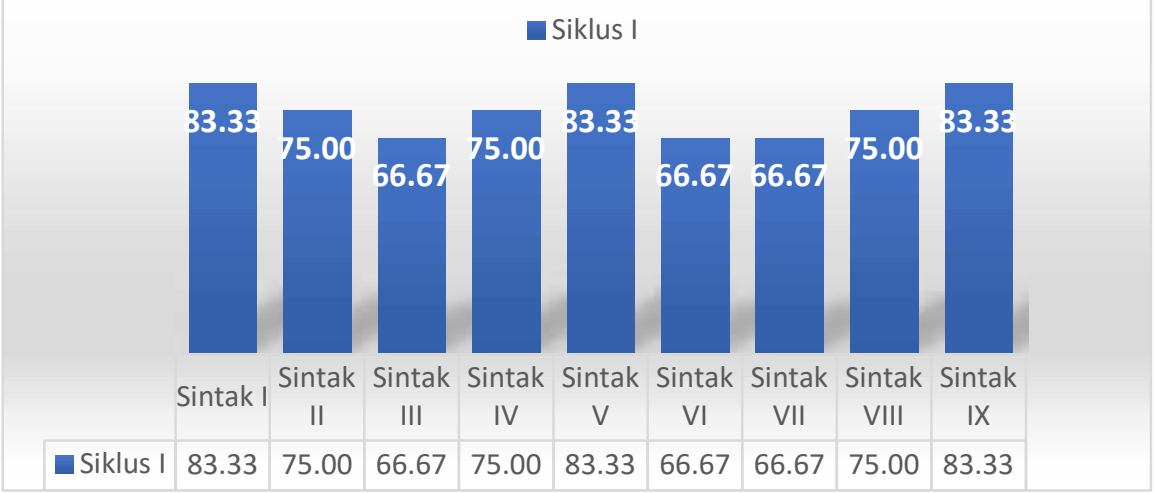

Grafik 1. Persentase Sintak Model Pembelajaran Cooperative Script

Pengamatan dari observer I menyatakan Langkah-langkah pembelajaran yang dilakukan sebagian besar sudah dilaksanakan dengan baik namun ada beberapa langkah pembelajaran yang harus diperbaiki. Pada Kegiatan Pendahuluan sebelum pelaksanaan sintak diperlukan motivasi agar Siswa lebih konsentrasi dan siap dalam pembelajaran, penyampaian tujuan pembelajaran agar lebih jelas dan mudah difahami Siswa . Kegiatan inti pada pelaksanaan sintak dari Model pembelajaran Cooperative Sript pada Langkah no 2 (Pendidik membagi wacana untuk dibaca dan dibuat ringkasanya) Siswa masih belum faham akan tugasnya masing-masing, masih terdapat Siswa yang merasa berat terhadap materi yang menjadi tanggung jawabnya, sehingga sebagian siswa belum dapat berperan secara maksimal sesuai dengan tugasnya . Langkah no 3 (Pembagian peran Siswa antara pembicara dan pendengar) masih dijumpai saling lempar siapa yang lebih dahulu melakukan peranya. Langkah no 4 (menfasilitasi Siswa dalam presentasi) belum sepenuhnya semua Siswa mendapat fasilitas terutama pengunaan media Pembelajaran yang kurang optimal, Langkah no 5 dan 6 (bertukar peran dengan pasangan) perlu pengelolaan waktu yang tepat agar seluruh Siswa mampu memerankan peranya dengan baik. Langkah no 7 diperlukan pengulangan peran agar siswa mampu berperan dengan baik, pada langkah 8 (menyimpulkan materi pelajaran) upayakan lebih banyak melibatkan Siswa agar lebih aktif dalam pembelajaran, Guru hanya menfasilitasi dan memotivasi agar siswa mampu menyimpulkan materi dengan banar, Langkah no 9 (Evaluasi) Diperlukan umpan balik secara lisan untuk mengetahui perkiraan kasar daya serap pelajaran, penggunaan Uji Kompetensi melalui pilihan ganda kurang bisa mengukur kemampuan Siswa secara detail.

Dari Pengamatan Observer II menyatakan bahwa Langkah-langkah pembelajaran yang dilakukan sebagian besar sudah dilaksanakan dengan baik namun ada beberapa catatan yang terkait langkah pembelajaran yang harus diperbaiki, diantaranya pada langkah Kegiatan Pendahuluan : Pastikan semua Siswa tenang 
sebelum berdo'a bersama, dibutuhkan motivasi agar Siswa lebih konsentrasi dan siap dalam pembelajaran, rumusan tujuan pembelajaran dibuat lebih simpel dan mudah difahami Siswa. Kegiatan inti pada: Langkah no 3 (Pembagian peran Siswa antara pembicara dan pendengar) kurang optimal dan penguasaan kelas belum maksimal sehingga masih dijumpai saling lempar siapa yang lebih dahulu melakukan peranya, Langkah no 5 dan 6 (bertukar peran dengan pasangan) perlu sebuah pemanfaatan media pembelajaran agar mempermudah dan mempersingkat durasi waktu agar seluruh Siswa mampu memerankan peranya dengan baik. Langkah no 7 perlu dilakukan agar anak lebih faham peran masing-masing, pada langkah 8 (menyimpulkan materi pelajaran) perbanyak melibatkan Siswa dalam menyimpulkan materi pelajaran untuk lebih meningkatkan pemahaman materi pembelajaran, langkah no 9 (Evaluasi) Diperlukan umpan balik secara lisan untuk mengetahui perkiraan kasar daya serap pelajaran, penggunaan Uji Kompetensi melalui soal yang membutuhkan pemikiran kreatif dengan variasi jawaban yang beragam

Pengamatan terhadap keaktifan Siswa sesuai dengan kajian pustaka dilihat dari 8 aspek , Menurut kedua observer didapatkan data pengamatan secara garis besar, apabila keaktifan dikategorikan dan 3 keaktifan (Keaktifan rendah, sedang dan tinggi) dengan kreteria keaktifan rendah apabila skor perolehan 1-4, keaktifan sedang 5-6, keaktifan tinggi 7-8, apabila disandingkan dengan data keaktifan pra siklus dapat dilihat dari grafik berikut :

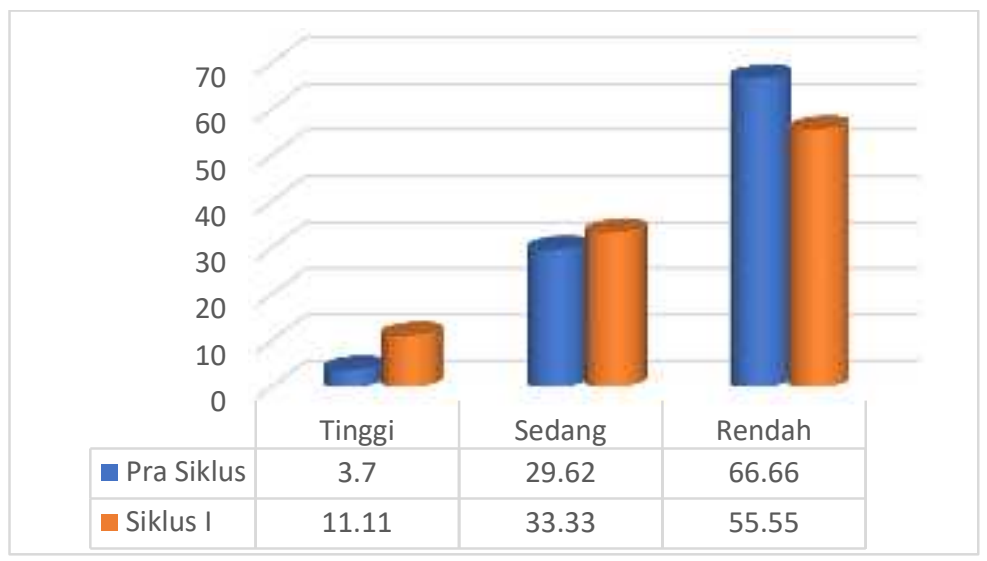

Grafik 2. Keaktifan Siswa Pra Siklis dan Siklus I

Dari grafik diatas diketahui bahwa keaktifan Siswa pada kategori sedang dan tinggi mengalami peningkatan setelah dilakukan tindakan, persentase Siswa yang berkategori kekatifan rendah mengalami penurunan dari kondisi pra siklus ke siklus I. Indikator keberhasilan PTK kategori keaktifan ini adalah, Siswa dengan kategori keaktifan Rendah maksimal 35,60\%, Sedang minimal 60,70\% dan tinggi 13,70\% dari tabel dan grafik diketahui persentase kekatifan rendah 55,55\%, Sedang 33,33\% dan tinggi $11,11 \%$ karena belum sesuai dengan indikator keberhasilan, maka PTK harus di dilanjutkan pada siklus II.

Berdasar tes tertulis yang dilakukan pada siklus I diketahui bahwa rata-rata nilai yang diperoleh Siswa untuk Mapel PAI Bila dibandingkan dengan hasil belajar Siswa 
pada kondisi awal (pra siklus) ini sudah mengalami peningkatan, dapat dilihat pada Grafik berikut :

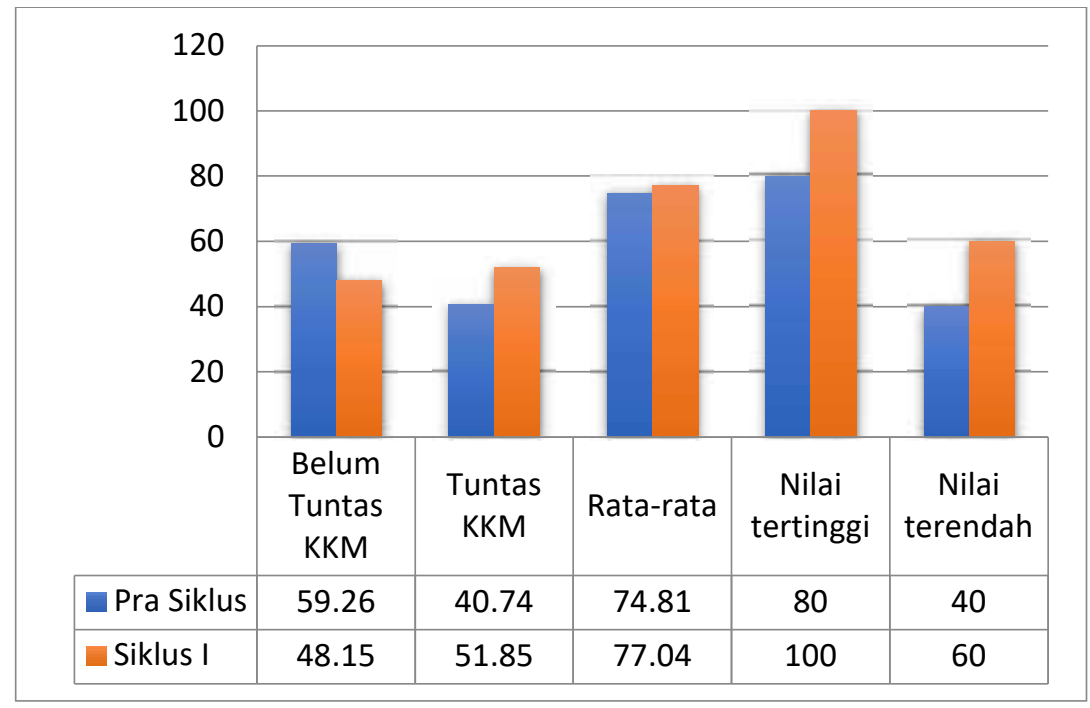

Grafik 3. Nilai Siswa Pra Siklus dan Siklus I

Jika dilihat dari grafik diatas bahwa hasil belajar Siswa mengalami peningkatan setelah dilakukan tindakan, persentase Siswa yang belum tuntas mengalami penurunan dari kondisi pra siklus ke siklus I demikian juga dengan rata-rata nilai Siswa juga mengalami peningkatan. Indikator keberhasilan PTK ini adalah, PTK dikatakan berhasil jika persentase Siswa yang nilai hasil belajarnya sudah tuntas KKM 75 adalah minimal 80\% dari 27 Siswa kelas VIID, dari tabel dan grafik diketahui persentase ketuntasan baru mencapai 51,84\%, karena belum sesuai dengan indikator keberhasilan tindakan maka PTK harus di dilanjutkan pada siklus II.

\section{SIKLUS II}

Dilakukan untuk melakukan perbaikan-perbaikan pelaksanaan pembelajaran berdasar data kedua observer yang meliputi pengamatan dari pelaksanaan sintak model pembelajaran Cooperative Script , pengamatan terhadap keaktifan Siswa dan hasil belajarn siswa

Pengamatan terhadap pelaksanaan pembelajaran pada siklus II dilakukan oleh 2 Observer dalam pelaksanaan sintak model pembelajaran Cooperative Script dengan memberikan skor dan kreteria yang sama dengan siklus I, data pengamatan ini dijadikan pertimbangan dan salah satu penentu keberhasilan peserta didik dalam peningkatan keaktifan dan pencapain hasil belajar sesuai dengan indikator keberhasil penelitian, dengan memperhatikan berbagai faktor penghambat dan pendukung pelaksanaan penelitian, berbagai hal yang diindikasikan dapat menghambat pencapaian indikator untuk diantisipasi dan di minimalisir baik yang datang dari diri Peneliti/Guru, siswa dan lingkungan. Dari pengamatan kedua Observer didapatkan data pelaksanaan sintak dalam grafik berikut : 


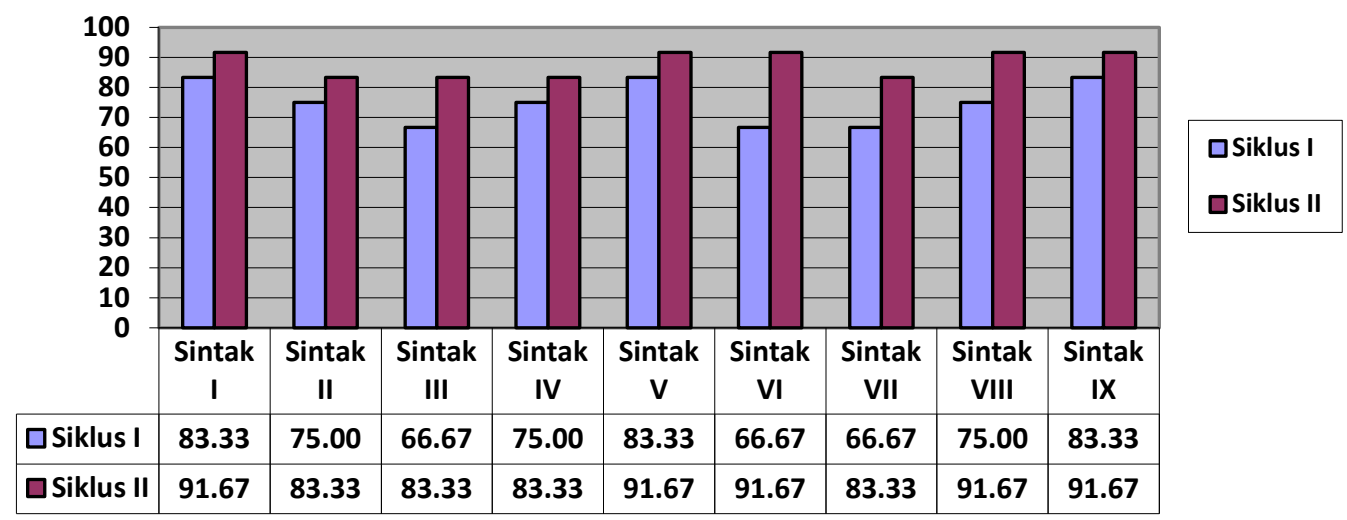

Grafik 4. Persentase Sintak Model Pembelajaran Cooperative Script

Secara umum berdasarkan observasi dari Observer 1 Pelaksanaan pembelajaran sudah sengat baik, sudah ada perbaikan dari siklus 1 ke siklus II namun masih ada langkah pembelajaran pada kegiatan Pendahuluan sebagai pembiasaan diantaranya : Pembiasaan berdo'a , membaca Al Qur'an sebelum pelajaran, dan motivasi ketaatan kepada Allah SWT. Pada Kegiatan Inti : Saat presentasi pasangan masih ada keraguan dari siswa terhadap hasil kegiatanya hal ini menyebabkan rasa minder untuk mempresentasikan hasil kegiatanya, dan saling bertukar peran belum terlakasana dengan baik dikarenakan kemampuan siswa yang berbeda. Kegiatan Penutup : Penugasan mandiri harus diberikan untuk memotivasi anak belajar.

Menurut Observer II Pelaksanaan pembelajaran sudah sengat baik, dibandingkan dengan pelaksanaan pada siklus II namun masih ada langkah pembelajaran yang baik dan harus ditingkatkan untuk sangat baik yaitu : Pendahuluan : Persipan fisik dan mental Siswa Kegiatan Inti : Saat Diskusi pasangan dan presentasi pasangan. Kegiatan Penutup : Penugasan mandiri terstruktur . Kegiatan pembelajaran sudah terlaksana dengan sangat baik, walaupun dari observer satu memberikan catatan untuk terus mengoptimalkan setting pembelajaran dan penggunaan media pembelajaran, dari Observer dua mencatat tentang pentingnya proses penyimpulan pelajaran untuk memotivasi peran Siswa didalamnya. Tetapi dari keduanya menyimpulkan bahwa pembelajaran terlaksana dengan sangat baik.

Keaktifan siswa dalam pembelajaran sudah ada peningkatan, Peningkatan Keaktifan siswa dalam pembelajaran terlihat pada kekompakan dalam berpasangan, dan lebih memahami akan peran masing-masing, sehingga siswa berusaha untuk lebih faham terhadap materi pelajaran, peningkatan lainya terlihat pada tanggapan terhadap presentasi pasangan sehingga proses pembelajaran tidak monoton didominasi oleh Guru Bila dibandingkan dengan Kekatifan Siswa pada kondisi Siklus I dan Siklus II ini sudah mengalami peningkatan hal dapat dilihat pada grafik berikut : 


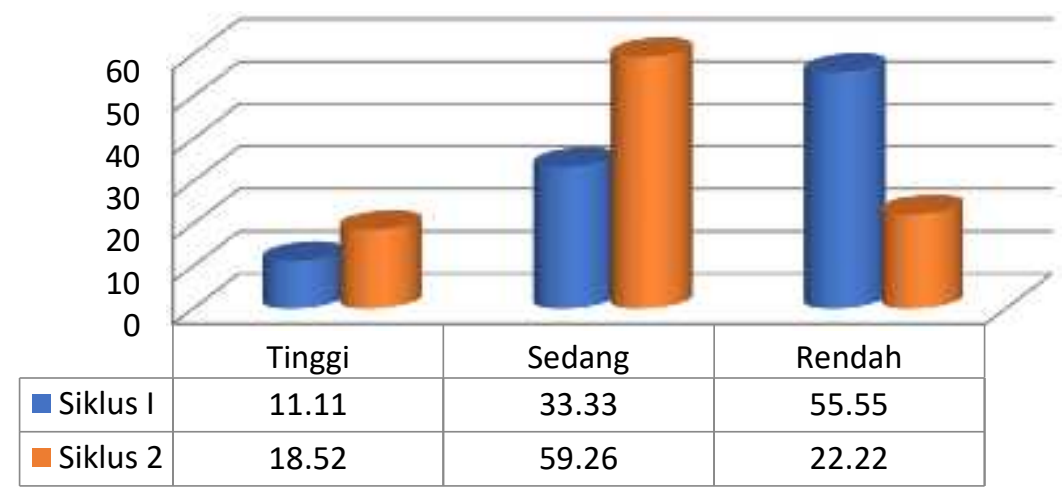

Grafik 5. Keaktifan Siswa dalam Siklus I dan Siklus II

Berdasar tes tertulis yang dilakukan pada siklus II diketahui bahwa rata-rata nilai yang diperoleh Siswa untuk Mapel PAI , Apabila dibandingkan dengan hasil belajar Siswa pada kondisi Siklus I sudah mengalami peningkatan, ini dapat dilihat pada Grafik berikut :

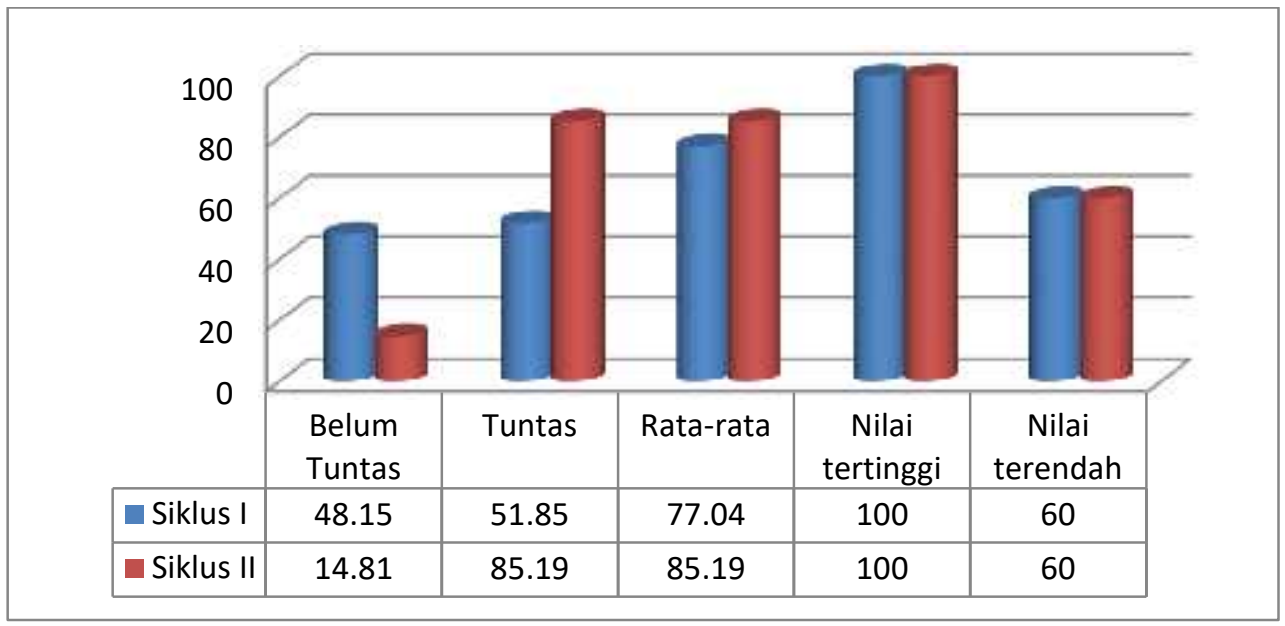

Grafik 6: Nilai Siswa Siklus I dan Siklus II

Dilihat dari tabel diatas bahwa hasil belajar Siswa mengalami peningkatan setelah dilakukan tindakan pada siklus II, persentase Siswa yang belum tuntas mengalami penurunan dari kondisi pra siklus ke siklus I demikian juga dengan ratarata nilai Siswa juga mengalami peningkatan.

Indikator keberhasilan PTK ini adalah, PTK dikatakan berhasil jika persentase Siswa yang nilai hasil belajarnya sudah tuntas KKM 75 adalah minimal 80\% dari 27 Siswa kelas VIID, dari tabel dan grafik diketahui persentase ketuntasan mencapai $85,19 \%$, karena sudah sesuai dengan indikator maka PTK , maka PTK sudah berhasil dan tidak dilanjutkan pada siklus berikutnya

Keaktifan dan hasil belajar Siswa sangat ditentukan oleh bagiamana mereka melakukan proses pembelajaran, Proses pembelajaran yang monoton hanya dengan ceramah, tentu kurang berdampak bagi keaktifan dan keberhasilan Siswa dalam mencapai hasil belajar yang tinggi sehingga tujuan pembelajaran dan pemahaman 
Siswa pada materi pelajaran tersebut tidak maksimal. Langkah-langkah pembelajaran Cooperative Script mampu meningkatkan keaktifan dan hasil belajar Siswa pada Mata Pelajaran PAI dan BP dari hasil penelitian ini menunjukkan bahwa setiap langkah yang dilakukan oleh Guru harus dilakukan dengan lebih kreatif agar dan menarik, hal ini dapat dilihat dari hasil Observasi dari kedua Observer.

Pada siklus I Guru telah merencanakan dan melakukan tindakan dengan menggunakan metode Pembelajaran Cooperative Scrip sesuai dengan sintak, tetapi pelaksanaan belum optimal, hal ini terjadi karena adaptasi Siswa terhadap metode baru, dan kesiapan Guru dalam mengelola kelas dengan metode tersebut, walaupun secara umum pelaksaan sudah baik tapi ada beberapa point penting yang menjadi catatan Observer untuk perbaikan.

Setelah dilakukan diskusi dan refleksi, kekurangan dan kelemahan pada siklus I untuk diperbaiki pada langkah pembelajaran pada siklus II yaitu : (a) Guru lebih mempersiapkan setting pembelajaran dengan menyiapkan Siswa dalam pembelajaran dari fisik dan mental, (b) Guru lebih mengoptimalkan langkah pembelajaran yang mendapat penilaian baik (skor 2), seta mempertahankan langkah pembelajaran yang mendapat penilaian sangat baik (skor 3), (c) Guru memanfaatan media pembelajaran dengan maksimal, (d) Guru dalam pemberian umpan balik lebih terbuka terhadap kesalahan dan kekurangan Siswa, (e) Guru harus memberikan reward pada pasangan teraktif, (f) Guru dalam melakukan Uji Kompetensi lebih bervariatif, dalam bentuk soal maupun tekhnik.

Keaktifan Siswa pada siklus I sudah ada peningkatan dibandingkan keadaan pra siklus, dari yang berkategori rendah menjadi sedang, kategori sedang menjadi Tinggi dan mereka yang berkategori tinggi mampu mempertahankan posisinya, walaupun belum mencapai indikator keberhasilan PTK. Melihat hasil belajar Siswa pada siklus I mengalami peningkatan dari yang belum tuntas menjadi tuntas KKM, Siswa yang belum tuntas memiliki persentase yang menurun, walaupun itu semua belum menunjukkan keberhasilan dalam Penelitian Tindakan Kelas ini.

Pada Siklus II Kegiatan Pembelajaran dengan metode Cooperative Scrip yang dilakukan oleh Guru sudah sangat bagus, hal ini berdasar pada hasil pengamatan kedua Observer, walaupun masih ada beberapa langkah pembelajaran yang membutuhkan penyempurnaan, tapi secara umum proses sudah berjalan dengan sangat baik, yang perlu diperhatikan dalam pembelajaran adalah terus mengoptimalkan setting pembelajaran dan penggunaan media pembelajaran, dari Observer II mencatat tentang pentingnya proses penyimpulan pelajaran untuk memotivasi peran Siswa didalamnya. Tetapi dari kedua Observer menyimpulkan bahwa pembelajaran terlaksana dengan sangat baik.

Analisis data keaktifan Siswa menujukkan dari kondisi awal (Pra Siklus),siklus I dan siklus II, mengalami peningkatan yang cukup berarti, pada siklus II persentase yang memiliki kategori rendah mencapai $18,52 \%$, terget penurunan dari Siswa kategori rendah pada pra siklus $66,66 \%$ mengalami penurunan pada akhir tindakan minimal sebesar 20\%. $=22,22 \%$ sudah mencapai target indikator keberhasilan tindakan. Lebih jelas dapat dilihat pada grafik berikut : 


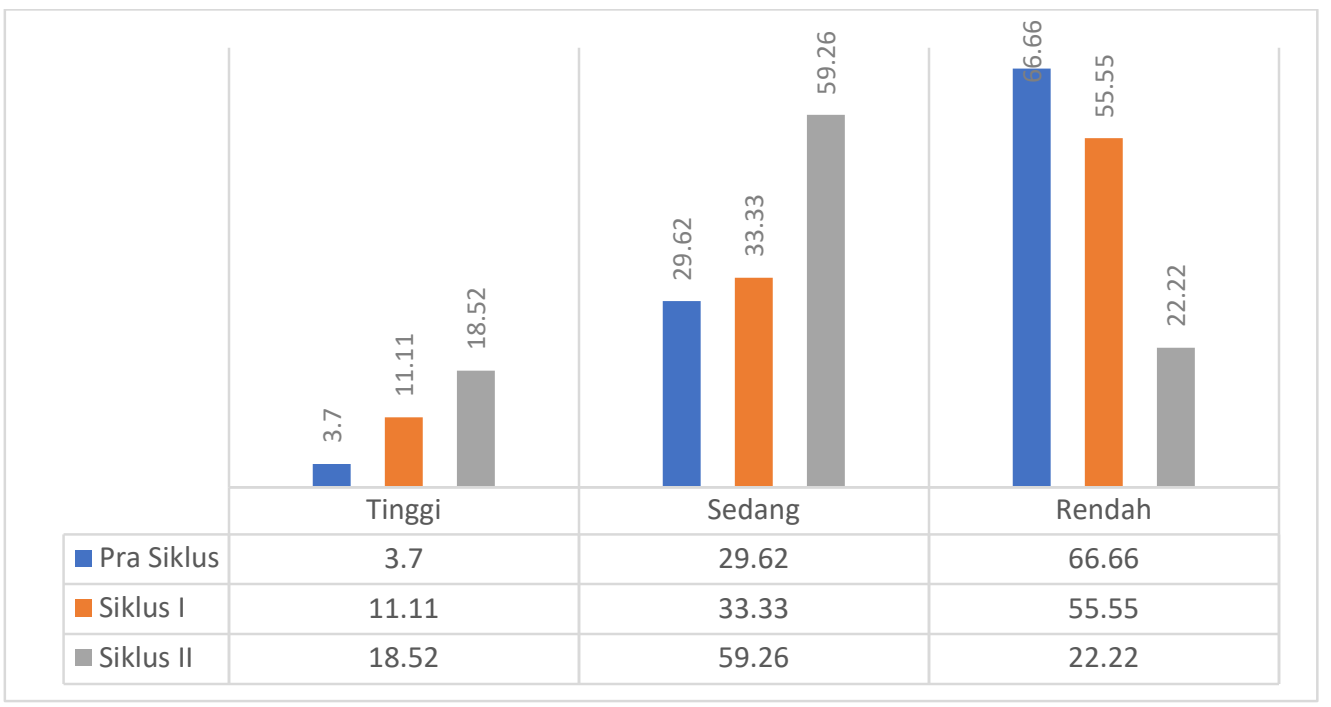

Grafik 7: Keaktifan Siswa Pra Siklus, Siklus I dan Siklus II

Dari grafik diatas dapat diketahui bahwa ada peningkatan Keaktifan sedang 29,64\%, keaktifan tinggi 44,44\% dan keaktifan Rendah mengalami penurunan 14,82\%. Indikator keberhasilan PTK kategori keaktifan ini adalah, Siswa dengan kategori keaktifan Rendah maksimal 35,56\%, Sedang minimal 60,74\% dan tinggi 13,70\% dari tabel dan grafik diketahui persentase keaktifan rendah 18,52\%, Sedang 59.26\% dan tinggi 22,22, Keaktifan ini sudah sesuai dengan indikator keberhasilan, maka PTK sudah berhasil dan selesai pada siklus II saja.

Dari Analis data hasil belajar Siswa menunjukkan dari kondisi awal (Pra siklus), ke siklus I dan siklus II, mengalami peningkatan yang cukup berarti, persentase hasil belajar pada siklus II sudah mencapai target (Indikator kinerja) bahkan melebihi, data ini menunjukkan bahwa proses pembelajaran yang dilakukan oleh Guru memberikan dampak bagi peningkatan hasil belajar Siswa, untuk lebih jelas dapat dilihat dari grafik berikut.

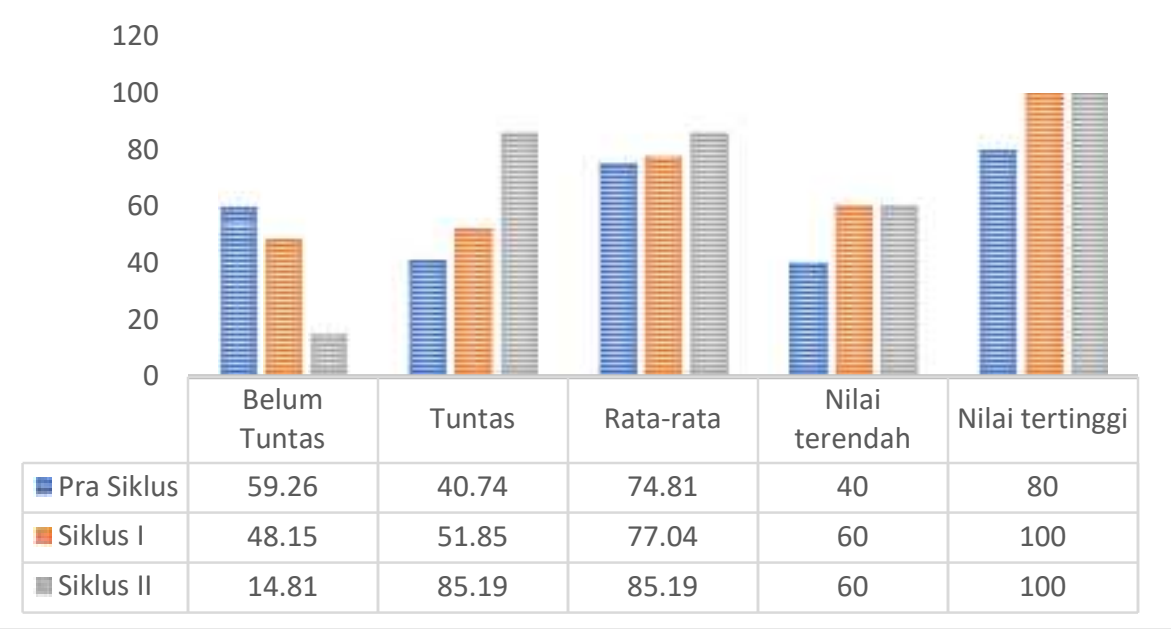

Grafik 8 : Hasil belajar Pra Siklus, Siklus 1 dan Siklus II 
Dari grafik diatas dapat diketahui bahwa ada peningkatan ketuntasan $11,11 \%$ $(40,74 \%-51,85 \%)$ dari pra siklus ke siklus I dan 33,34\% (51,85\% - 85,19\%) dari siklus I ke siklus II Siswa yang tuntas KKM. Terjadi penurunan Siswa yang belum tuntas KKM 11,11 \% dari Pra siklus ke siklus I (59,26\% - 48,15\%) dan penurunan 33,34\% $(48,15 \%$ - 14,81), dari rata-rata nilai ada peningkatan dai kondisi pra siklus ke siklus I sebesar 2,23 (74,81 - 77,04) dan peningkatan dari siklus I ke siklus II 8,15 (77,04 $85,19)$. Dari hasil belajar Siswa yang sudah sesuai dengan indikator keberhasilan penelitian, maka PTK sudah dapat dikatakan berhasil dan selesai pada siklus II.

\section{SIMPULAN}

Hasil Penelitian Tindakan Kelas dengan judul : “ Peningkatan keaktifan dan hasil belajar PAI Siswa kelas VII D SMP Negeri 2 Penawangan melalui metode pembelajaran Cooperative Script Dapat disimpulkan sebagai berikut : Hasil Penelitian menunjukkan bahwa melalui metode cooperative script pelaksanaanya secara umum baik dan mengalami perbaikan dari siklus I dan siklus II sehingga pada akhir siklus mendapatkan predikat sangat baik. Peningkatan Keaktifan Belajar dari Pra Siklus , Siklus I dan II menunjukkan bahwa prosentase keaktifan Siswa ketegori rendah mengalami penurunan yakni $66,66 \%-55,55 \%-22,22 \%$, kategori sedang mengalami peningkatan dari $29,62 \%$ - 33,33\% - 59,26\% adapun Siswa dengan kategori keaktifan tinggi mengalami peningkatan dari 3,70\% - 11,11\% - 18,52\%.

Penerapan Model Pembelajaran Cooperative script mampu meningkatkan hasil belajar Siswa, perolehan nilai pada pra siklus - siklus I - Siklus II secara berurutan, dari 27 Siswa yang belum tuntas KKM 75 dari 59,26\% - 48,15\% - 14,81\% kemudian Siswa yang mencapai dan melampaui KKM 75 dari 40,74\% - 51,85\% $85,19 \%$ dengan peningkatan nilai rata-rata kelas dari 74,81 - 77,04 - 85,19 setelah adanya tindakan. Indikator keberhasilan hasil belajar Siswa setelah uji kompetensi pada akhir proses pembelajaran minimal nilai >= KKM mencapai $80 \%$ dan nilai rata-rata minimal mencapai 78,00. Siswa yang memperoleh nilai dibawah KKM mengalami penurunan minimal $10 \%$. dilihat dari keaktifan dan hasil belajar sebelum dan sesudah tindakan maka dapat dikatakan bahwa penelitian ini berhasil.

Saran yang dapat disampaikan : agar proses belajar mengajar PAI dan budi Pekerti lebih efektif dan memberikan hasil yang optimal bagi Siswa, maka 1) dalam pelaksanakan pembelajaran dengan model Cooperative Script memerlukan persiapan yang cukup matang, berupa persiapan Setting kelas agar waktu yang tersedia bisa efektif, 2) Pemanfaat media pembelajaran untuk mempermudah pemahaman Siswa dalam diskusi Kelompok dengan pasangannya, 3) Pengaturan peran masing-masing pasangan dan motivasi keefektifan Siswa dalam pembelajaran. 4) upaya peningkatkan prestasi belajar Siswa, Guru hendaknya lebih sering melatih dengan berbagai metode pembelajaran,walau dalam taraf yang sederhana, dimana Siswa dapat menemukan pengetahuan baru, memperoleh konsep dan keterampilan.

\section{DAFTAR PUSTAKA}

Hamdani, 2011, Strategi Belajar Mengajar, Bandung : CV Pustaka Setia.

Hariyanto dan warsono, 2014, Pembelajaran Aktif Teori dan Asesmen, Bandung : PT Remaja Rosdakarya. 
Natalina, Mariani. "Penerapan Model Pembelajaran Cooperative Script Untuk Meningkatkan Aktivitas Dan Hasil Belajar Biologi Siswa Kelas VII5 SMP Negeri 14 Pekanbaru Tahun Ajaran 2012/2013." BIOGENESIS (Jurnal Pendidikan Sains dan Biologi) 10.1 (2013): 44-52.

Meilani, Rima, and Nani Sutarni. "Penerapan model pembelajaran cooperative script untuk meningkatkan hasil belajar." Jurnal Pendidikan Manajemen Perkantoran (JPManper) 1.1 (2016): 176-187.

Noor, Aisjah Juliani, and Norlaila Norlaila. "Kemampuan Pemecahan masalah matematika siswa dalam pembelajaran matematika menggunakan model cooperative script." EDU-MAT: Jurnal Pendidikan Matematika 2.2 (2014).

Sufazen, Nurulita. "Keefektifan Model Cooperative Script Terhadap Hasil Belajar IPS." Journal of Elementary Education 3.2 (2014): 57-63.

Tafsir Ahmad, 2011, Ilmu Pendidikan dalam Perspektif Islam, Bandung : PT Remaja Rosdakarya. 